\title{
O pós-moderno cor-de-rosa
}

Michel Amary

\section{Resumo:}

Este ensaio busca retomar as discussões iniciadas por Fredric Jameson sobre o pós-modernismo e sua aplicação na contemporaneidade. Nosso objetivo é procurar no pós-modernismo alguma objetividade capaz de responder aos anseios concretos de liberdade e de promover um estado verdadeiramente novo e humano que a arte promete. Para isso passamos primeiro por uma contextualização histórica sobre origem do pós-moderno; após, sua caracterização em expressões artísticas; e por fim, a relação da arte com a política em uma análise crítica sobre o seu potencial de emancipação.

Palavras-Chave: Modernismo - Pós-Modernismo - Jameson - Ideologia Cinismo 
O meu interesse por artes visuais foi marcado profundamente por dois artistas. Van Gogh foi quem me chegou primeiro, ainda na infância, por influência de uma professora na escola que nos apresentou seus traços carregados e seus tons de amarelo. Os céus que faziam curvas, as pinceladas curtas que coloriam os campos de trigo e girassóis, e carregavam os rostos de expressividade, eram um grande atrativo para os olhos, mas não chamavam tanto à atenção como a sua história de vida repleta de angústia, loucura que culminou em suicídio. Pequeno, eu ainda não tinha a clara consciência de como a sua pintura era um ato de revolta contra a sociedade que o reprimia (ARGAN 2006, p. I23). Eu não percebia que um quarto da casa amarela em Arles era a própria representação de seu mundo fechado, enclausurado, incompreendido. Eu gostava das histórias sobre seus surtos e ataques de loucura. Ouvia com interesse o caso da orelha que cortou para se autorretratar, confundindo a loucura com o gênio. Acreditava que era um ato de coragem e devoção pela arte do qual poucos seriam capazes, sem imaginar que a mutilação algum dia poderia ser considerada uma forma de expressão artística. ${ }^{I}$ Van Gogh viveu seu tempo da maneira que lhe cabia no mundo. A modernidade nascera trazendo consigo uma transformação radical na maneira de ser no mundo e no modo de percebê-lo. A industrialização capitalista veio com a urbanização e a transformação das cidades, acompanhada da miséria dos campos; o fazer mecânico distanciava o sentimento humano do trabalho; as novas relações de trabalho estranhava a relação do sujeito com a terra, com o pão, com o seu produto, para depositá- la na finalidade do lucro; a multidão aparecia, mas a vida era cada vez mais individual e solitária. O homem moderno atingira a maioridade. A autonomia aparecera como o grande slogan dos modernos impondo novas formas de perceber e se colocar no mundo; autonomia da razão frente aos sentidos, autonomia do sujeito perante os objetos, autonomia do homem em relação à natureza, autonomia do indivíduo, do social. Na arte, coube à geração moderna uma resposta, ela não poderia ficar presa no passado em um mundo que cobrava de si mesmo autonomia das velhas formas. Ela rompeu com a tradição e o classicismo, mas a ruptura não vinha desacompanhada de certo desconforto com o mundo, um incomodo que viria posteriormente a ser o "mal do século". Charles Baudelaire captou bem o espírito da época para essa geração do modernismo histórico nas artes, ele celebrava o novo, mas rejeitava a vul-

I Os "Van Goghs da body art" vão de casos extremos como o de Rudolf Schwarzkogler, que amputa o próprio pênis em um ensaio fotográfico (Documenta V, I972), à Marina Abramovic, que convida o público a usar objetos cortantes sobre seu corpo (Ritmo O, I974). 
garidade estética da burguesia. Nessa nova sociedade pragmática e finalista, o artista, o flâneur, o dândi perderam seu lugar. Na busca por esse novo tempo, pelo presente, o artista era transformado em um esgrimista que desfere seus golpes de pincel sobre o vazio da tela (BENJAMIN I989, p. 68); também era visto como um trapeiro que, marginalizado, percorria as ruas atrás dos trapos e dos signos dessa sociedade que desejava transformar (id. ibid., p. I6). As metáforas de Baudelaire caberiam perfeitamente em Van Gogh, que se sentia excluído pela sociedade e desajustado nesse novo tempo. Van Gogh viu a miséria no campo, sentiu a multidão em Paris, tentou se ajustar à ordem social e foi rejeitado. ${ }^{2}$ A pintura foi a maneira que encontrou de existir no mundo, como sua loucura foi a personificação de como a crença de seu tempo no progresso mutilava a experiência humana.

Foi só mais adulto, ao modo do filho de Andreas Huyssen, ${ }^{3}$ que voltei a me interessar por arte. Novamente, a obra deste artista não era a primeira coisa a chamar minha atenção. Não tinham mais tintas, palhetas, telas, mas feltro, gordura, ações, segredos, mistérios a se desvendar. Nada superava a mitologia por trás de Joseph Beuys. Sobrevivente de um acidente de avião, salvo por povos locais da Crimeia, curado por feltro e cera, dono de um misticismo e excentricidade únicos, dissidente do exército alemão, artista engajado. Beuys já nos representa outro tempo em que as aspirações racionalistas do tempo dos primeiros modernistas desenvolveram-se, colocando o progresso e o novo como horizonte a ser consumido. É uma mudança de personalidade de época, o consumo se torna a exigência do mundo para existirmos e o novo vem como a representação do progresso nas últimas promoções do mercado. "O novo é evidentemente moderno, e quando este declina ao esbarrar nos seus limites imanentes, o primeiro se degrada, o seu efeito de choque se amortece, e a novidade torna-se moda, cuja obsolescência é industrialmente programada" (ARANTES I998, p. 2I). Já no início do século XX o modernismo artístico tinha virado tradição, e a necessidade do novo nos impunha a necessidade de dessublimação da arte que reverberou nas vanguardas tardias do modernismo. O modernismo fez assim como uma tradição da ruptura em que cada interrupção é um novo começo (cf. PAZ I984, p. I7). Essas vanguardas foram

2 Giulio Garlo Argan nos conta que Van Gogh dedicou-se ao apostolado religioso, tornando-se pastor e missionário entre os mineiros de Borinage, mas a Igreja oficial, que era solidária aos patrões, o expulsou dessa vocação (cf. ARGAN 2006, p. I24).

3 Andreas Huyssen, em seu texto "Mapeando o pós-moderno", descreve como seu filho Daniel, de apenas cinco anos, se interessou por arte ao brincar sobre as pedras de uma instalação de Joseph Beuys na 7ª Documenta de Kassel, em ig82 (cf. HUYSSEN i99i, pp. I5-16). 
O pós-moderno cor-de-rosa

positivas, afirmativas, construtivistas; elas visavam, por meio do capitalismo industrial ou do socialismo, "disseminar a arte no cotidiano pela estandardização dos protótipos formais criados pelo artista" (FABBRINI 2006, p. 2), pelo design, pela propaganda, pela arquitetura. Mas também tivemos vanguardas negativas, líricas, pulsionais, que criticavam esse compromisso com a racionalidade, buscando, no embaralhamento da arte com a vida, uma poetização do gesto (FABBRINI 2006, p. 2). Beuys não é um vanguardista do alto modernismo, mas certamente um herdeiro deste embaralhamento. O seu engajamento, mesmo que político, não teve relação apenas com a maneira de ser no mundo, mas com a maneira de ser da arte no mundo. Beuys se via como um transmissor em um mundo em que a racionalização capitalista inviabiliza o nosso acesso à arte (cf. ARGHER 200I, p. II4). A sua missão não era apropriar a linguagem artística às exigências do mundo, mas, ao contrário, comunicar ao mundo o que é a arte e, assim, libertá-lo para ela. Quando Beuys se cobria de mel e ouro, vestia-se com feltro e gordura, dormia com coiotes, compunha com feltro e cera o seu ritual xamânico, acreditava estabelecer um contato espiritual com um mundo de outra ordem que transmitia uma energia elementar que só a arte possui e torna a vida possível. Em um mundo em que o sensível está interditado como simples mercadoria, está justificada a busca incansável pelo transcendente. Beuys via-se como o mensageiro desse mundo que buscava reconectar a arte com a vida em um sentido plenamente político. O seu conceito ampliado de arte foi a expressão mais genuína de sua militância artística de fazer político; ao nos convidar para intervir de maneira lúdica no cotidiano, nos colocávamos como escultores sociais. ${ }^{4} \mathrm{Na}$ narrativa de sua lenda enigmática sobre um tempo mágico primitivo, na mescla entre arte e política, e na possibilidade de nos sentirmos artistas, foi que acordei do sono dogmático com a curiosidade de uma lebre frente à obra de arte. ${ }^{5}$

Essas duas experiências artísticas que me despertaram representam momentos diferentes da história da arte que frequentemente são contrapostos

4 O conceito ampliado de arte deve ser tomado ao pé da letra. Para Beuys, "todo homem é um artista" no sentido em que na dignidade moral do trabalho humano em geral se encontra uma dimensão estética. A arte ampliada está no interior de todos os campos das atividades humanas, conscientizando seu potencial criativo e libertador, e por isso o homem como um escultor da sociedade em que vive é artista. "A escultura social é o resultado de um escultor incansável que aceita qualquer tipo de material [...] suas esculturas assim como suas actions, suas manifestações, suas teorias, seu engajamento político, enfim, tudo aquilo que a sua moral artística impunha como tarefa diária, também faz parte dessa escultura social" (BEUYS i993, p. 9I).

5 Referência a uma famosa ação de Beuys: Como explicar imagens a uma lebre morta, de I965. 
por nós. ${ }^{6}$ Em geral, o modernismo, na utopia de transformar o mundo, foi considerado antiburguês (ainda que possamos inserir o seu aparecimento em uma ordem completamente burguesa e identificar em suas vanguardas tardias experiências compromissadas com o capitalismo, como a Bauhaus e o Futurismo), já o pós-modernismo é, na maioria das vezes, caracterizado pela corrupção crítica e elogio da sociedade de consumo (embora experiências como as de Beuys vão na direção contrária disso). Em uma bela comparação entre Um par de botas, de Van Gogh, e Diamond Dust Shoes, de Andy Warhol, Fredric Jameson marca bem essa distinção. Van Gogh apresentava "uma transformação violenta e proposital do mundo objeto opaco do camponês" (JAMESON I996, p. 33) - mundo pré-industrial em que "as árvores frutíferas são apenas velhos galhos exauridos brotando de um solo pobre; os habitantes dos vilarejos são reduzidos a esqueletos, caricaturas de uma grotesca tipologia das feições humanas" (id. ibid., p. 33), em que a miséria e a pobreza se colocam como o estado brutal opressivo do estilo de vida capitalista - "na mais gloriosa materialização de pura cor em pintura a óleo" (id. ibid., p. 33), o modernismo mantinha o gesto utópico de transformar a situação de profunda degradação em que se vivia em uma sociedade mais viva, expressiva e humana. Em contraposição, Jameson caracterizava o pós-moderno no limiar da obra de Warhol apenas como manifestação mercadológica, uma coleção aleatória de simulacros de produtos de supermercados ou reprodução de "objetos sem vida, pendurados na tela como se fossem nabos, tão desprovidos de sinais de sua vida anterior como uma pilha de sapatos que ficaram em Auschwitz" (id. ibid., p. 35). A crítica feroz de Jameson a Warhol não desconsiderava a possibilidade de sua obra se manifestar com sentido crítico ao fetichismo da mercadoria, mas esse caráter crítico, se houvesse, era superficial e sem profundidade. O colorido de Van Gogh queria resgatar a experiência do olhar e dos sentidos fragmentados pela nova divisão do trabalho capitalista, era um ato compensatório e utópico que almejava transformar um mundo ferido pelo racionalismo e pela industrialização, a partir da desalienação do sujeito. Em Warhol, se passava o contrário, era o falso brilho das imagens e propagandas que surgiram com o desenvolvimento desse mundo industrial quem decorava a arte, revestindo-a com uma frivolidade gratuita que contribuía para mortificar o olhar reificado do espectador (cf. id. ibid., pp. 36-37). Claro que essa

6 Agora deixo minha experiência particular para falar sobre como esses objetos foram apreendidos historicamente pelo coletivo social; por isso a frase vai do "me" ao "nós", abandonamos o singular para falar no plural. 
comparação não leva em conta que entre modernos e pós-modernos podemos falar de modernismos e pós-modernismos, mas ela nos abre os olhos para a intenção geral do espírito nesses dois momentos, que apesar das diferenças pode nos remeter a uma ligação germinal entre ambos.

A pós-modernidade aparecera justamente como a consumação da estetização da vida pretendida pelo modernismo, em uma sociedade ideal futura. As vanguardas do modernismo, ao tentarem resgatar a existência alienada do sujeito pela desestetização da arte, pela negação constante ao que se impunha como tradição artística acreditando que assim se alterava o curso do mundo, de repente se viram no pós-modernismo (cf. ARANTES I998, p. 34). O ato criador de Marcel Duchamp, o último dos modernos, foi o xeque-mate no que restava de arte contemplativa, passiva e retiniana. Os ready-mades, como A fonte, desceram com o conceito de "Belo" descarga a baixo para dar lugar a uma dúvida primeira: o que é arte? A Pop Art, com seus quadrinhos, latas de Coca-Cola e sopas Campbell, também enfatizava, a sua maneira banalizada e generalizada, a mistura da arte com a vida cotidiana. As cadeiras de Joseph Kossuth, os parangolés de Hélio Oiticica, os grafites de Jean-Michel Basquiat traziam como marca essencial algo do gesto inaugural duchampiano. O deslocamento do "Belo" para a periferia das discussões estéticas decretou o "fim da arte", ou pelo menos para certo tipo romântico de arte. Assim, no pós- moderno se concretizou a previsão de G. W. Hegel, "o fim da arte consiste na conscientização da verdadeira natureza filosófica da arte" (ANDERSON I999, p. II7), no momento em que apenas a decisão intelectual pode dizer o que é arte ou o que não é, se tudo é arte ou se nada é, é que encontramos a verdadeira liberdade artística.

No entanto, essa estetização da vida que supostamente teria decretado o fim da arte não cumpriu inteiramente o seu programa. Se a arte está no dia a dia, a nova sociedade por ela imaginada, livre e humana, não chegou e está longe de acontecer. A crítica de Karl Marx ao anarquismo de Proudhon (cf. JAMESON I996, p. 268), que via na abolição do mercado por si a solução para uma sociedade mais justa, é homóloga a situação da arte; a "arte pela arte", apesar de seu esforço heroico, não foi suficiente para carregar a humanidade nas costas. Talvez por isso o pós-moderno vira e mexe volte ao moderno com um pedido de socorro ou esperança por alguma perspectiva futura. Para além das relações positivas ou negativas entre moderno e pós-moderno - continuidade ou ruptura -, se quisermos recuperar na crítica as possibilidades de mudanças genuínas que traduzam esse momento, devemos tratar principalmente da relação arte e sociedade. Se a arte desce do sublime pedestal em que se encontrava para fazer parte do 
mundano universo dos mortais, sua crítica necessariamente deve abandonar a pura questão subjetiva de gosto ou preferência estilística para se basear na periodização histórica da sociedade em que foi produzida. Devemos deixar de nos encantar com os olhos para, com as mãos na lama, conseguir, quem sabe, colocar os pés no chão. Não nos interessa acentuar um ideal de arte que diz "pertencer a um mundo mais elevado, mais puro, a um mundo cotidiano" (BÜRGUER 20I2, p. 36), para nós isso implica na própria eliminação de sua realização. ${ }^{7}$ Devemos ter claro que, enquanto instituição, a arte possui uma função social que não está nas objetivações artísticas individuais, mas integrada a materialidade histórica em constante movimento na prática cotidiana; dissociá-la disso é neutralizar sua ação transformadora, tornando a experiência por ela proporcionada puramente ideal (cf. id. ibid., pp. 36-39). O jogo é dialético, a materialidade social é fundamental para a revolução formal e experimental das artes, tal como a expressão e humanização artística são ímpares para a transformação do contemporâneo mundo de objetos, mercadorias e cálculos. A codeterminação no modo de abordar o objeto artístico e a sociedade não é mera recusa da autonomia da arte, "trata-se muito mais de constatar que o status de autonomia da arte dentro da sociedade burguesa não resta inatacável, sendo antes um produto precário do desenvolvimento da sociedade como um todo" (id. ibid., p. 57). A autonomia da arte não significa que ela é recebida isoladamente, sem um marco de condições materiais, mas que, enquanto instituição social, sua crítica deve ser interna sem que seja manipulada por outros sistemas (o que ainda não pode ser consumado) (cf. id. ibid., p. 60). Como consequência de tudo isso, traçamos duas diretrizes metodológicas: primeiro, a crítica de arte deve levar em conta a historicidade social; segundo, alertados por Bürger, devemos nos atentar para as possíveis apropriações ideológicas do pós-modernismo, como também o sentido oculto nelas impresso (cf. id. ibid., p. 40). Esperamos que, assim, possamos dar conta de nosso desafio: procurar no pós-modernismo alguma objetividade capaz de responder aos

7 Peter Bürger nos mostra como isso acontece do seguinte modo: "Ao receptor individual, a arte permite satisfazer, ainda que apenas idealmente, necessidades que se acham banidas da sua práxis cotidiana. Na fruição da arte, o indivíduo burguês, mutilado, experimenta a si mesmo como personalidade. Mas como o status da arte se encontra dissociado da práxis cotidiana, essa experiência não produz consequências, isto é, não pode ser integrada à práxis. Ausência de consequências não significa o mesmo que ausência de função, mas designa uma função específica da arte na sociedade burguesa: a neutralização da crítica” (BÜRGUER 20I2, pp. 38-39). Assim, quando a arte remete apenas a valores de cultura em um âmbito ideal, sem conexão com o dia a dia, é sua própria realização que é abortada. 
anseios concretos de liberdade e de promover um estado verdadeiramente novo e humano que a arte promete.

O primeiro caminho para essa investigação é realizar uma contextualização histórica. Qual é o ponto em que se dá a origem do pós-modernismo? Essa questão não é nem um pouco fácil de responder com precisão. Andreas Huyssen tende a colocar a geração de I960 (Duchamp, Cage, Warhol) como a primeira pós-moderna. $\mathrm{O}$ ato inaugural de Marcel Duchamp certamente influenciou muito a linguagem pós-moderna, mas podemos considerá-lo uma antecipação (os primeiros ready-mades, por exemplo, datam do final dos anos I9IO, começo dos anos I920). O dadaísmo de Duchamp ainda se apresentava como uma vanguarda moderna; era uma contestação da razão social da arte e seus sistemas de valores que continuavam a reproduzir no modernismo a sociedade burguesa. Da luz dos iluministas aos disformes cubistas, toda a arte moderna teria sido sempre a repetição dos mesmos dilemas pela transformação do sentido formal da obra; o gesto mudava, a luz variava, a forma misturava, mas sempre estava presente a inexorável áurea plástica da obra de arte, o sagrado, o inatingível, a arte retiniana para ser consumida, apreciada. A crítica de Duchamp aos modernos aparece nesse sentido, de uma arte produtora de objeto de valor, representando a superioridade da intelectualidade e do talento humano como legado narcísico da civilização capitalista; a ironia de Duchamp ao colocar bigodes na Monalisa era um manifesto contra toda tradição e sociedade às quais se opunha, e não mero pastiche. $O$ franco-americano e os dadaístas apareciam como antiartistas, recolocando a arte como parte da vida e a vida como processo da arte. O Dadá ainda era moderno. Andy Warhol e os pops estão mais próximos aos pós-modernos, mas, tal como Duchamp, se colocavam contra a codificação tradicional do alto modernismo, não como "uma rejeição do modernismo per se, mas uma revolta contra a versão do modernismo que havia sido domesticada nos anos I950, incorporado por um consenso liberal-conservador" (HUYSSEN I99I, p. 34), a arte pop era um resgate do modernismo às suas origens antiburguesas, se colocava no casamento entre arte e vida como uma crítica à sociedade pacificada pelo consumo, mas também com as ressalvas de Jameson, ao desaparecer com distinção entre cultura erudita e cultura popular de massas, massificava a arte como as indústrias faziam com seus produtos. Em sua contradição, o pop viria como um limiar entre moderno e pós-moderno.

A dificuldade de pontuarmos precisamente a origem do pós-moderno pode ser elucidada melhor se levarmos em conta o modo em que o mundo estava disposto sócio, político e economicamente. Jameson, um dos primeiros grandes teóricos a se debruçar sobre o pós-modernismo de maneira totali- 
zante nas artes, localizou-o a partir dos anos I970. A mudança do capitalismo industrial para o capitalismo avançado em I945 seria um ponto de ruptura muito abrupto para o nascimento do pós-modernismo, as vanguardas modernas não se extinguiriam da noite para o dia. Houve um tempo de maturação e de transformação da realidade social; e a localização temporal de Jameson era coerente aos fatos, ainda que não nos desse muitos indicadores relevantes da conjuntura econômica e histórica. Por isso, pedimos ajuda. De um lado, o geógrafo David Harvey apontava o surgimento do pós-moderno como reflexo da recessão de I973, que apresentou um novo paradigma de desenvolvimento econômico mudando as posições entre mercado financeiro e governos; flexibilizado e desregulamentado "esse sistema especulativo e inquieto foi a base das várias formas de cultura pós-moderna - uma sensibilidade intimamente ligada à desmaterialização do dinheiro, à característica efêmera da moda, ao excesso de simulação nas novas economias" (ANDERSON i999, p. 94). Por outra via, Alex Callinicos apontava os anos 1970 como o surgimento do pós- moderno não por consequência de grandes rupturas no modelo econômico internacional, mas como um desgaste das vanguardas revolucionárias no entre guerras, esmagadas por Hitler e Stalin, posteriormente; o que tínhamos era resultante da "degradação paulatina do próprio modernismo à medida que se tornava mais acomodado e integrado aos circuitos capitalistas do pós-guerra" (id. ibid., p. 95), o pós-modernismo era a derrota política da geração dos anos I960. Independente da perspectiva, o coro uníssono nos permite aceitar os anos I970.

Perry Anderson, o historiador da turma, ainda contribui muito para nosso diagnóstico de época ao enquadrar o pós-modernismo em três eixos históricos. O primeiro é a desclassificação da ordem dominante a partir da Segunda Guerra. O declínio da aristocracia burguesa repleta de orgulho e autoconsciência pela ascensão de uma nova classe de gerentes, administradores e funções sem identidade fixa em um universo monetário sem rigidez trouxe consigo o fim do academicismo artístico ligado intrinsecamente à representação do mundo burguês. "Com a morte do mundo burguês, ficou faltando o contraste estético" (id. ibid., p. I02). O segundo eixo é marcado pela evolução tecnológica e midiática no final dos I960. Se o modernismo ganhou um grande estímulo com o advento da fotografia e a transformação da cidade burguesa pelas máquinas, o pós-modernismo começa com a televisão a cores e suas "cataratas de tagarelice visual"; se "o modernismo era tomado por imagens de máquinas; agora, o pós-modernismo é dominado por máquinas de imagem" (id. ibid., p. I05). Por fim, o último eixo refere-se a uma política sem nuances dos anos I970 e I980. O início da Guerra Fria cessou os ventos 
revolucionários, as revoltas do Maio francês extinguiram-se sem deixar vestígios; a Primavera de Praga foi esmagada pelo Pacto de Varsóvia; as guerrilhas na América Latina, inspiradas em Cuba e Guevara, se liquidaram; a Revolução Cultural de Mao-Tsé Tung se disseminou em terror; a greve dos mineiros britânicos em I973 ascendeu Margareth Thatcher e seu similar estadunidense Ronald Reagan (id. ibid., p. IO7). Desse cenário de derrota a modernidade chega ao fim com a impossibilidade de outras ordens sociais, de alternativas políticas, de uma nova sociedade tão cara à ela. O pós-moderno consolida-se com a vitória do neoliberalismo. ${ }^{8}$

Não é por menos que Jameson mapeou a pós-modernidade como a lógica cultural do capitalismo tardio. A pós-modernidade não apareceria como "mera ruptura estética ou mudança epistemológica", ela era "o sinal cultural de um novo estágio na história do modo de produção reinante" (id. ibid., p. 66), as mudanças da terceira fase do capitalismo marcado pela revolução tecnológica, pelos grandes conglomerados de comunicação e a informação em tempo real, pelas multinacionais e a aldeia global, pelo deslocamento da fábrica para bens e serviços, foram cataclismáticas para tudo aquilo que persistia a modernização, consolidando a hegemonia do capitalismo e a ideologia do progresso, inclusive na cultura. A resistência do modernismo ainda datava de um mundo pré-industrial, se os modernos queriam a transformação do mundo ela veio por outras mãos. A modernização ficou a cargo da industrialização, dos meios de comunicação e das agências de publicidade. Nesse mundo contemporâneo "a cultura necessariamente expandiu-se ao ponto de se tornar praticamente coextensiva à própria economia" (id. ibid., p. 67), o pós-moderno veio como a superação de qualquer forma social que relutasse a se modernizar nos padrões ditados, a pá de cal sobre a persistência de um passado industrial, "a saturação de cada poro do mundo com o soro do capital" (id. ibid.) que o elegeu, enquanto regime hegemônico, tendência estética dominante.

Agora em um segundo momento nós devemos apontar os reflexos partilhados dessa conjuntura nos sistemas autônomos de artes e no sujeito contemporâneo. Desse novo território nasceu o homem contemporâneo e sua maneira esquizofrênica de se relacionar com o mundo. As mudanças no mundo objetivo não tiveram consequências importantes apenas no ciclo de negócios, padrões de emprego e relações de classes, mas também no modo de ver, sen-

8 Isso não significa dizer que os artistas pós-modernos são neoliberais em suas expressões individuais, mas que enquanto instituição esse novo momento da arte nasce de um contexto neoliberal. 
tir, interagir e existir. As experiências estéticas do pós-moderno evidenciam o esmaecimento dos afetos, a perda de qualquer senso ativo da história nessa subjetividade. O homem contemporâneo purgado de tudo aquilo que não seja moderno rompe com o passado como velharias ultrapassadas e faz do presente, que deixa de ser uma relação temporal, o seu próprio espaço. Esse presente isolado invade o sujeito como espaço de práxis material, mas expressa sua própria incapacidade de unificar ou se relacionar com o tempo. A esquizofrenia aparece como um amontoado de significantes soltos e não relacionados no tempo que nos aparece como sintoma na nostalgia do passado. Jameson nos aponta isso na moda retrô do cinema. Filmes como American Graffiti (I973), de Lucas, Chinatown (I974), de Polanski, ou até, curiosamente, Body Heat (I98I), de Kasdan, e Star Wars (I977) do mesmo Lucas, nos remete a incapacidade patológica de lidarmos com o passado e a história (cf. JAMESON 2006, pp. 26-30). No interior desse sujeito monádico, a produção cultural "não pode mais olhar diretamente com seus próprios olhos para o mundo real em busca de um referente, ao contrário, ela deve, como na caverna de Platão, traçar suas imagens mentais do mundo nas paredes que a confinam" (id. ibid., p. 30). Como pastiche ou simulacro, deslocamos a história real para uma versão estereotipada que evidencia nossa própria perda de referencial histórico em nosso presente esmaecido; usamos o passado para reproduzir nossas visões do presente de modo objetivo e degradado.

Muito pode ser dito dessa anomalia, nos limitemos a dois aspectos, a morte do sujeito e o pastiche. A lógica do mercado de um capital fictício, sem lastro e fundamento, reverberou na produção artística sem caráter referencial. O que vemos é a morte do sujeito (pelo menos aquele moderno), o desaparecimento de um eu referencial centrado em um sujeito individual que no modernismo se caracterizou pelo gênio, por um homem organizacional perdido no presente. O alto modernismo, como vimos, carrega não apenas a visão de mundo singular de um eu único que se expressa na genialidade artística, como também uma temporalidade utópica que conhece as consequências do passado em seu presente e vislumbra uma sociedade futura; a morte do sujeito evidencia que, presos na pós-modernidade, nós voltamos ao passado apenas como tentativa de buscar alguma esperança futura que a perpetuação do presente nos nega. No entanto, a herança que o modernismo nos deixou é apenas a imitação, o simulacro e o pastiche. O modernismo com a genialidade do sujeito individual realizou todas as combinações formais possíveis, restando-nos apenas a imitação de estilos mortos, por isso o modo de se referir nostalgicamente ao passado sempre aparece como pastiche. O pastiche torna-se a própria linguagem do pós-moderno. Diferente 
da paródia que em sua mímica "revela o ridículo na natureza particular desses maneirismos estilísticos (imitados), particularmente pelos seus excessos e excentricidades" (id. ibid., p. 22), o pastiche aparece como "o discurso em uma língua morta" (id. ibid., p. 23). A sátira da paródia aparece como um contraste de uma nova gramática contra a autoridade de um referente ridicularizado, o pastiche não, ele é apenas "uma máscara estilística, uma prática neutra de tal mímica, desprovida do motivo oculto da paródia, sem o impulso satírico, sem o riso [...] o pastiche é a paródia pálida, a paródia que perdeu o seu senso de humor" (id. ibid., p. 23). O pastiche aparece apenas como um esvaziamento cínico que se apropria do referente e o imita sem pudor, produzindo uma inflação de imagens em contraposição a deflação de sentidos. Como linguagem predominante do pós-moderno, o pastiche é a forma como nos referimos ao passado apenas enquanto nostalgia. Como não há nada mais de novo, nada mais que possa ser feito e pensado, volta-se ao passado como seu próprio sepultamento. O pastiche revela que o novo no pós-moderno só existe como um aprisionamento do passado, como self-service simbólico em que os signos e os referentes já perderam significado (isso implica que o fim das vanguardas não significou absolutamente o fim da arte moderna; na volta do pós-moderno, ela sobrevive na linguagem artística do presente, embora seu ideário e imaginário tenham declinado [cf. FABBRINI 2006, p. 6]).

A completar a descentralização do indivíduo pela morte do sujeito, o hibridismo e a indiferenciação de discursos e signos pelo pastiche, poderíamos chamar a atenção para uma última característica gritante do pós-moderno: o hiperespaço. A perda de referência do passado já se mostrava como resultado de um privilégio na pós-modernidade do espacial sobre o temporal. Não são poucas as preferências artísticas no pós-modernismo pelo espaço, os happenings e as instalações nas artes visuais, a poesia concreta e visual na literatura, a volta do teatro de rua, o cinema tridimensional e, claro, a rainha do espaço, a arquitetura. No entanto, essa mudança de referência diz respeito a uma mudança na própria noção de espaço e movimento que ainda esse sujeito descentralizado (mas criado no modernismo) não desenvolveu capacidade cognitiva de perceber. Jameson nos mostra isso ao passear pelo Hotel Bonaventure no centro de Los Angeles, os grandes empreendimentos se apresentam hoje como um mundo completo capaz de proporcionar uma nova prática coletiva e um novo modo de se locomover no espaço. Como mundo completo, esses empreendimentos não visam mais se impor como uma linguagem utópica, eles se apropriam do léxico da cidade, como um substituto a ela; como modo de locomoção, as máquinas e os elevadores desses prédios inteligentes se colocam 
como a própria extensão do corpo humano, que "expandem os nossos sentidos e os nossos corpos até novas dimensões, ainda inimagináveis, talvez até, em última instância, impossíveis” (id. ibid., p. 3I). Esse hiperespaço supera a nossa capacidade humana de nos localizarmos, organizarmos e mapearmos em um mundo externo, o pós-modernismo nos mostra, então, que nos encontramos atrasados perceptivamente de um modo peculiarmente disforme em relação a nossa própria civilização.

Às vezes mais, às vezes menos, todas essas características apareciam partilhadas em artes autônomas, evidenciando esse novo período que Jameson retratou em um grande painel de época. Diferentemente de outros autores que já tratavam do embate entre moderno e pós-moderno, Jameson foi o primeiro a sair de sua área, a literatura, para mapear o pós-moderno de maneira global, unificante, encontrando características comuns que interligavam artes independentes. A supremacia do espaço e o hiperespaço faziam da arquitetura a arte privilegiada do pós-modernismo; o cinema viria logo depois com as suas compulsões nostálgicas e promessas de entretenimento; as artes plásticas se tornaram visuais, privilegiando as representações vazias da moda e do design, em detrimento do contexto; a literatura acompanhada de jocoso pastiche; e a teoria, que outrora era bem demarcada em seus domínios, com seu hibridismo de discursos. Com essas transformações no sujeito e na cultura concluímos nosso segundo passo.

Por fim, após a conjuntura histórica e caracterização de época nas artes, nos falta ainda realizarmos um último momento: relacionar a estética pós- moderna com a lógica capitalista. Para isso trocamos o Hotel Bonaventure pela praça Roosevelt no centro de São Paulo. Essa praça recém-vitalizada faz parte do projeto conjunto, entre o governo estadual e a prefeitura, de transformação do centro da cidade em um corredor de cultura, o que traria novos empreendimentos e outros tantos bons negócios. ${ }^{9}$ A restauração da praça Roosevelt, à primeira vista, cumpre bem "o intuito de criar grandes monumentos que sirvam ao mesmo tempo como suporte e lugar de criação de cultura e reanimação da vida pública” (ARANTES I99I, p. I64). Sua arquitetura repleta de concreto, como pós-moderna, faz-se indiferenciada do cinza da cidade, seu espaço de convivência torna-se um enorme chão plano em meio

9 A revitalização da praça Roosevelt faz parte de um projeto maior do poder público que tem na cultura a porta de entrada para a especulação imobiliária nas áreas esquecidas do centro de São Paulo. A grande pérola de toda essa movimentação política é o projeto encabeçado como Nova Luz. A urbanista Raquel Rolnik nos ajuda a entender e questionar todos esses processos em "Nova Luz: reflexões e alternativas ao projeto da prefeitura". 
O pós-moderno cor-de-rosa

aos prédios residenciais, que como guardas a vigiam o tempo inteiro. A perda da privacidade é compensada, no entanto, pela sombra que esses prédios vizinhos fornecem na ausência de árvores. Essa arquitetura, ainda que a meu ver seja pouco convidativa, tornou-se o novo espaço de convivência entre os jovens alternativos da classe média paulistana; a praça abandonada resgatou a Ágora grega com shows, debates, teatros e manifestações sociais. ${ }^{10}$ Reduto de inúmeros grupos de teatro e dos novos produtores de cultura, festivais como BaixoCentro, Anhangabaú da FelizGidade e Existe Amor em SP desceram a rua Augusta (que, inflacionada pelos aluguéis, deixou o visual underground para lá), colorindo a cidade de rosa com sua música, vídeos, arte e performances independentes.

A explosão desses novos produtores vem com uma roupagem assumidamente pós-moderna; "Fora do Eixo", como se denominam, apresentam-se em suas linguagens híbridas como uma nova tendência progressista, democrática e participativa, descontente com as práticas da esquerda tradicional, que chamam de rancorosa; pós-rancor, como se alcunham, ${ }^{\text {II }}$ assumem a morte da ideologia e propõem como alternativa de mudança a ocupação do espaço público com festa. ${ }^{12}$ Não é difícil vermos nessa juventude um predomínio do espacial, uma perda de referência histórica de luta política, uma nostalgia da cidade que não viveram e que querem ocupar, a ocupação como simulacro e a festa como pastiche, a linguagem visual carregada de tendências da moda, a fusão da publicidade com a animação cultural, a experiência situada apenas na vivência e a desqualificação de qualquer crítica como ideológica.

Como uma geração que cresceu no pós-modernismo, nós não podemos condená-la moralmente por seus gostos estilísticos, mas devemos chamar a atenção, mesmo correndo o risco de ser categorizado por eles como rancorosos, para o que nela aparece como característica intrínseca, o esmaecimento da crítica. O pós-modernismo não é um problema em si, tampouco a ocupação do espaço público, a questão é que essas iniciativas vêm sendo aparelhadas

IO Sobre a apropriação da praça como Ágora grega de forma crítica, vale a pena conferir "A ideologia do 'lugar público' na arquitetura contemporânea”, de Otília Fiori Arantes, copilado em O lugar da arquitetura depois dos modernos (São Paulo: Edusp, 1995).

II Os termos e as autodefinições podem ser encontrados no "Glossário Fora do Eixo", por eles mesmos produzido. Como os conceitos do pós-modernismo rapidamente desaparecem, são substituídos ou mudam repentinamente, a versão consultada está disponível em: http://passapalavra. info/2013/02/7297I.

I2 Sobre o perfil festeiro dessas manifestações, encontramos ótimas referências no coletivo Zagaia, inclusive uma colaboração de Sílvio Carneiro, pesquisador Latesfip: "BaixoCentro: uma festa e nada mais". 
como lógica do capital. Claro que reconhecemos na antiga esquerda arestas e descrenças, entretanto suas manifestações de uma forma ou de outra sempre acabaram esbarrando em um questionamento político. Desencantados com a política, essa geração pós-moderna do ocupar por ocupar, ou seja, ocupar em si, sem algum fim, acaba, sem se dar conta, corroborando com o processo de gentrificação ocorrido no centro, iniciado pelo governo do Estado e a especulação imobiliária. Ocupam como se fosse um território livre conquistado pelos cidadãos de bem. Não conhecem a história do lugar. Não se perguntam o que ocorreu com os mendigos e usuários de droga que ali estavam e foram espancados ou chacinados pela polícia. ${ }^{13}$ Não entendem por que as favelas e cortiços do centro misteriosamente pegam fogo e em um passe de mágica viram estacionamentos e empreendimentos milionários. ${ }^{\mathrm{I}}{ }^{4}$ Ignoram que os moradores que ali construíram suas vidas terão que se mudar com a alta dos aluguéis para os confins da cidade, que terão que morar longe do emprego e que não poderão usufruir de toda a cultura (bibliotecas, teatros, museus, cinemas) que ali será produzida com a chegada da tal Nova Luz. ${ }^{15}$ Com a melhor das intenções desconhecem que a cultura de baixa qualidade que consomem está sendo apropriada por esse coletivo de novos produtores (que já estão dentro das secretarias e dos ministérios ${ }^{16}$ para monopolizar as verbas de editais,

I3 A região conhecida como "cracolândia" no centro de São Paulo foi testemunha de graves violações do direito à dignidade humana e à vida promovidas pela Polícia Militar por ordem do governador Geraldo Alckmin como política de combate às drogas. Às ações foram exaustivamente veiculadas pelos meios de comunicação e sofreram duras críticas de especialistas em tratamento de usuários de drogas e de grupos de direitos humanos. Coincidentemente, a "cracolândia" está no centro da Luz, região imaginada para esse corredor de cultura que em suas proximidades já conta com a Sala São Paulo, a Escola de Música Tom Jobim, a Pinacoteca do Estado e a Estação Pinacoteca, o Museu da Língua Portuguesa e o Museu de Arte Sacra.

I4 No ano retrasado, houve um aumento significativo dos casos de incêndios nas favelas de São Paulo, principalmente aquelas que passavam por processo de litígio ou estavam em áreas de reurbanização. $\mathrm{Na}$ maioria das vezes, famílias ficavam desabrigadas enquanto a área queimada se tornava empreendimentos ou estacionamentos. Não por menos, esses incêndios passaram a ser relacionados com a valorização imobiliária, o que gerou uma CPI na Câmara de Vereadores (que em 2010 já tinha desativado o programa de prevenção a incêndios à favelas) que pecou nas investigações e nos resultados. Tudo isso está relatado no artigo "Arquitetura da destruição", publicado pela revista Rolling Stones, na edição 56 de maio de 20II.

I5 Muitas pessoas estão ameaçadas com a revitalização dos centros, além dos comerciantes que estão sendo desapropriados de suas lojas e da alta no valor dos aluguéis, comunidades como a Júlio Prestes e do Moinho correm o risco de se tornarem novos Pinheirinho.

I6 Diego Zaccheta, do jornal O Estado de S. Paulo, noticiou em seu blog no dia 6 de maio de 2013 que Juca Ferreira, "pai" desses novos produtores de cultura durante o ministério de Gilberto Gil e hoje secretário de cultura da cidade de São Paulo, nomeou a cargos comissionados os organizadores do Existe Amor em SP em sua secretaria. 
O pós-moderno cor-de-rosa

vender cases às empresas multinacionais e campanhas políticas eleitoreiras. ${ }^{17}$ E, pior, não têm ideia de que suas festanças estão indicando às construtoras e imobiliárias os potenciais pontos de convivência a serem apropriados. Animado, vemos esse público "polimorfo em situações de fluidez" (ARANTES I99I, p. I64) em uma relação de indução e distração (longe do que Walter Benjamin pensara ${ }^{18}$ na qual a crítica se esvai e a cultura e a política tornam-se apenas bens de consumo.

Os questionamentos não feitos tornam evidente o esmaecimento da crítica nessas investidas pós-modernas. No entanto, tudo isso nos revela um diagnóstico muito mais profundo do que o puro e simples esvaziamento do senso crítico. Apesar de termos, de um lado, pessoas que ocupam a cidade com sua inocência e boas intenções, de outro temos a cultura como um discurso ideológico sequestrado pelo sistema vigente para a articulação de seus programas e projetos. Apesar de ser algo relativamente novo no Brasil, não é de agora que a cultura se torna política privilegiada do Estado; desde Beaubourg, as políticas de animação cultural vêm sendo o verdadeiro emblema do capitalismo. Não é incomum em crise "restringir o orçamento do sistema previdenciário e investir no campo da cultura em expansão (de retorno seguro e rápido)" (id. ibid., p. I64). Os festivais "independentes" desses novos produtores de cultura vão em direção a políticas como a Nova Luz e as Viradas Culturais (que ironicamente realizam a virada cultural no sentido que Jameson propôs, animação cultural do capitalismo tardio), que escondem em seus alvarás a gentrificação e a exclusão social. Como a cidade desordenada

I7 $\mathrm{O}$ crescimento do Fora do Eixo como agitador cultural principal da cidade gerou muita polêmica. Muitos artigos e debates foram produzidos a respeito disso na academia e fora dela. Sobre as práticas do grupo destaco o mestrado de Danielle Maciel pela ECA-USP, Midiativismo: entre a democratização e a assimilação capitalista, apresentado nos seminários de quarta do Paulo Eduardo Arantes, e os artigos do Passa Palavra, "Existe consenso em SP: reflexões sobre a questão da cultura" (partes I e 2) e "Comentando o Existe consenso em SP".

I8 A teoria da distração de Benjamin é descrita por Otília Arantes com Brecht: "Não é difícil reconhecer a lição de Brecht que invertendo o negativo em positivo transforma a distração em ponto de vista interessado e vice-versa, a atenção suprema da consciência estética, em entorpecimento como transe wagneriano hipnotizado" (ARANTES I99I, p. I63). Não era a arte aurática que traria a conscientização, mas a desenvoltura de um público desatento sobre uma "arte de massa, produzida para ser reproduzida" (id. ibid.). Benjamin "acreditava que a recepção coletiva reproduzida pelo aparato técnico emerge para liberar o potencial cognitivo até então aprisionado nos domínios confinados da cultura afirmativa" (id. ibid.), no entanto, observamos o contrário do que se imaginou: a "relação distraída não é mais do que apreensão superficial e maximamente interessada da obra enquanto bem de consumo" (id. ibid., p. I64). Em resumo, "a distração estética do especialista amador, há um tempo atenção flutuante e conhecimento rotinizado, desaguaria na conformação de uma ordem social superior" (id. ibid., p. I63). 
não tem mais para onde crescer, os negócios se expandem para lugares por eles esquecidos e abandonados; e como o "progresso" e o "desenvolvimento" que trazem se resumem aos lucros que não vão partilhar com a população local, fazem da cultura o espelhinho para trocar com a sociedade civil que, animada com novos ganhos culturais, não vê problemas na expulsão violenta e violação de direitos humanos dos que ali vivem. Como diria Benjamin, "não há testemunho de cultura que ao mesmo tempo não seja testemunho de barbárie" (BENJAMIN I996, p. I87).

Assim, a perda do potencial crítico de um lado é compensada com o cinismo de outro. Bem observado por Peter Sloterdijk, a crítica - que em sua forma original se oferecia como instrumento de desarticulação da fantasia ideológica, pelo contraste entre o discurso e a prática social - faliu no pós-modernismo com o aparecimento de uma racionalidade cínica, que além de conhecer os efeitos de suas ações, as justificam como ações morais e necessárias. Cientes da distância entre a máscara ideológica e a realidade social, o ideólogo contemporâneo sabe que defende interesses particulares, conhece bem as consequências de seus atos, mas mesmo assim não os renuncia; desmascarados os mecanismos ideológicos, continua a insistir em suas ações, legitimando-as racionalmente. $\mathrm{O}$ cinismo se mostra irredutível diante do argumento crítico uma vez que busca sua fundamentação no próprio ato de tornar nua a discordância manifesta, ele se legitima assumindo que há tal clivagem entre discurso e prática, mas que é necessário agir de tal maneira; a crítica se torna inoperante porque ela revela o segredo oculto no mecanismo ideológico e, apesar disso, tudo continua a funcionar como tal. Hoje "eles sabem muito bem o que estão fazendo e fazem assim mesmo" (SLOTERDIJK I987, p. 29).

Com o que nos foi dado, não sei se ainda estamos prontos para restabelecer a crítica como instrumento de superação ideológica. Todavia, quando nos perguntávamos anteriormente sobre a possibilidade de alguma linguagem crítica em que pudemos produzir outra relação com o pós-moderno e que pudéssemos indicar a nós mesmos um caminho futuro, anos mais tarde, no novo milênio, ao perceber que a condição pós-moderna arraigada pela ordem vigente aparece esteticamente incapaz e sem autonomia para nos dar algo de novo, e que politicamente a estetização da vida se dá como barbárie, tudo indica que devemos chegar à mesma conclusão de Hal Foster: "a noção de pós- moderno, independente dos maus usos que fizeram dela depois, não era uma noção que a esquerda devesse se render" (FOSTER apud ANDERSON I999, p. II8). De modo que assumir nossa falência e dependência com o passado nos parece mais digno! 


\section{Referências bibliográficas}

ANDERSON, Perry. As origens da pós-modernidade. Rio de Janeiro: Jorge Zahar, I999. ARANTES, Otília Beatriz Fiori. Os novos museus. Novos Estudos, São Paulo: Cebrap, n. 3I, I99I.

O envelhecimento do novo. In. Urbanismo em fim de linha. São Paulo: Edusp, I998.

ARCHER, Michael. Arte contemporânea: uma história concisa. São Paulo: Martins Fontes, 200I.

ARGAN, Giulio Carlo. Arte moderna. São Paulo: Companhia das Letras, I992.

BENJAMIN, Walter. Charles Baudelaire: um lírico no auge do capitalismo. São Paulo: Brasiliense, I989.

. Mágia e técnica, arte e política: ensaios sobre literatura e a história da cultura. São Paulo: Brasiliense, I996.

BEUYS, Joseph. Joseph Beuys in America: Energy Plan for the Western Man. Londres: Paperback, I993.

BÜRGER, Peter. Teoria da vanguarda. Cosac Naify: São Paulo, 2012.

FABBRINI, Ricardo. O fim das vanguardas. Cadernos da pós-graduação, Campinas: Unicamp, v. 8, 2006.

HUYSSEN, Andreas. Mapeando o pós-moderno. In: BUARQUE DE HOLLANDA, Heloisa. Pós-modernismo e política. Rio de Janeiro: Rocco, I99I.

JAMESON. Fredric. Pós-modernismo: a lógica cultural do capitalismo tardio. São Paulo: Ática, I996.

. Virada cultural: reflexões sobre o pós-modernismo. Rio de Janeiro: Civilização Brasileira, 2006.

PAZ, Octávio. Os filhos do barro. Rio de Janeiro: Nova Fronteira, I984.

SLOTERDIJK, Peter. Critical of Cynical Reason. Minnesota: Universty of Minnesota Press, I987.

Michel Amary - Graduando em Filosofia pela Universidade de São Paulo.

michel.neto@usp.br 